\title{
Towards a new bound for a matrix norm
}

\author{
P. G. Popescu, E. I. SLuŞANSChi and V. PredA
}

\section{ABSTRACT.}

In this paper are given refinements of several classical inequalities like Jensen, Young and Heinz which are then applied to obtain new improvements of recent results. We also give a new bound for a matrix norm expression, related to a matrix inequality of Bhatia and Davis.

Acknowledgements. The work has been funded by the Sectoral Operational Programme Human Resources Development 2007-2013 of the Ministry of European Funds through the Financial Agreement POSDRU/159/1.5/S/134398.

\section{REFERENCES}

[1] Bhatia, R. and Davis, C., More matrix forms of the arithmetic-geometric mean inequality, SIAM J. Matrix Anal. A., 14 (1993), No. 1, 132-136

[2] Dragomir, S. S., A new refinement of Jensens inequality in linear spaces with applications, Math. Comput. Model., 52 (2010), No. 9-10, 1497-1505

[3] Horn, R. A. and Johnson, C. R., Matrix Analysis, Cambridge University Press, 2th edition, 2012

[4] Jensen, J. L. W. V., Sur les fonctions convexes et les inégalités entre les valeurs moyennes, Acta Math., 30 (1906), 175-193

[5] Kittaneh, F., On the convexity of the Heinz means, Integr. Equ. Oper. Theory, 68(2010), 519-527

[6] Kittaneh, F. and Manasrah, Y., Improved Young and Heinz inequalities for matrices, J. Math. Anal. Appl., 361 (2010), 262-269

[7] Rassias, T. M., Survey on Classical Inequalities, Kluwer Academic Publishers, Dordrecht, 2000

[8] Simic, S., Best possible global bounds for Jensens inequality, Appl. Math. Comput., 215 (2009), No. 6, 2224-2228

[9] Tapus, N. and Popescu, P. G., A new entropy upper bound, Appl. Math. Lett., 25 (2012), No. 11, 1887-1890

[10] Xiao, Z.-G., Srivastava, H. M. and Zhang, Z.-H., Further refinements of the Jensen inequalities based upon samples with repetitions, Math. Comput. Model., 51 (2010), No. 5-6, 592-600

[11] Zou, L. and Jiang, Y., Improved Heinz inequality and its application, J. Inequal. Appl., 2012:113

UNIVERSITY POLITEHNICA OF BUCHAREST

COMPUTER SCIENCE AND ENGINEERING DEPARTAMENT

SPLAIUl INDEPENDENŢEI 313, 060042 BUCHAREST, ROMANIA

E-mail address: pgpopescu@yahoo.com

UNIVERSity PoliteHNicA of BUCHAREST

COMPUTER SCIENCE AND ENGINEERING DEPARTAMENT

SPLAIUL INDEPENDENŢEI 313, 060042 BUCHAREST, ROMANIA

E-mail address: emil.slusanschi@cs. pub.ro

MATHEMATICS DePaRTMENT

UNIVERSITY OF BUCHAREST

ACADEMIEI 14, 010014 BUCHAREST, ROMANIA

E-mail address: preda@ fmi.unibuc.ro

Received: 04.12.2013; In revised form: 13.06.2014; Accepted: 15.06.2014

2010 Mathematics Subject Classification. 26B25, 26D15, 15A60.

Key words and phrases. Jensen inequality, Young inequality, Heinz inequality, refinement, Hilbert-Schmidt norm . Corresponding author: P. G. Popescu; pgpopescu@yahoo.com 